\title{
TWO DECADES OF DBFO ROADS IN THE UK AND SPAIN: AN EVALUATION OF THE FINANCIAL PERFORMANCE
}

\author{
by \\ Basilio ACERETE* and Mar GASCA \\ University of Zaragoza, Spain
}

and

\author{
Anne STAFFORD \\ Alliance Manchester Business School, University of Manchester, UK
}

\begin{abstract}
Road schemes are of major importance in the global PPP market. We focus on Design-Build-Finance-Operate (DBFO) arrangements covered by shadow toll or availability payment mechanisms, where the UK and Spain are key players. Now that a good number of DBFO schemes in the UK and Spain have been operational for well over half the contract period, there is scope for a detailed ex post evaluation of DBFO performance in both countries and an analysis of how the DBFO model has evolved. Preliminary results show that these contracts continue to be very expensive for public administrations, especially in the UK, where the financing costs and fee per kilometre are high. On the other hand, they are an easy source of revenue for the parent companies of the concessionaires, where the increased use of subordinated debt rather than equity seeks to reduce risk. However, despite circumventing the controversial hardtolling, some projects in both Spain and the UK present poor outcomes. Several other problems around these projects are identified, including lack of public accountability and transparency or poor governance, raising long-term questions around affordability and opportunities for further study.
\end{abstract}

Keywords: PPP, shadow tolls, availability payments, UK, Spain

JEL: H44, H54, M40

\section{$1 \quad$ Introduction}

Using private finance to provide public infrastructure and services traditionally funded and provided by public administrations is now a widespread practice. Since 1990, within Europe alone, around 1,860 Public-Private Partnership (PPP) projects with an estimated

This work was supported by the Spanish Ministry of Economy, Industry and Competitiveness under the project of the Spanish National Research and Development Plan ECO2015-66240$\mathrm{P}$ (MINECO/FEDER); and the Regional Government of Aragón and the European Social Fund through research project GESPÚBLICA S05. Email: bacerete@unizar.es

Annals of Public and Cooperative Economics @ 2018 CIRIEC. Published by John Wiley \& Sons Ltd, 9600 Garsington Road, Oxford OX4 2DQ, UK and 350 Main Street, Malden, MA 02148, USA 
value of $€ 369$ billion have been signed (EPEC, various years). Transport infrastructure is a significant element of PPPs, with roads playing an important part. Toll roads have been the largest area of growth, however Design-Build-Finance-Operate-(Maintain) $(\mathrm{DBFO}(\mathrm{M}))$ arrangements have also been used for roads projects where for political or practical reasons direct user tolling has not been seen as appropriate. DBFO(M) arrangements include shadow tolls, where the state pays the private operator an amount per vehicle travelling on the road, plus other forms of operating and maintenance contracts where payments are based on availability and active road management.

Within the DBFO(M) form of PPP projects the UK and Spain have been prominent alongside other countries including Portugal and Canada. The UK was an early adopter of shadow toll schemes, with nine schemes starting in the 1990s, and Spain imitated its model. As a good number of DBFO schemes in both countries have been operational for well over half the contract period, there is scope for a detailed comparison of DBFO performance in both countries and an analysis of how the DBFO model has evolved. Using the information gathered from UK and Spanish DBFO schemes, the objective of this paper is an ex post evaluation of the financial performance of the DBFO model since it was implemented in both countries, with empirical evidence aimed at addressing the following key questions:

- What are the institutional differences/similarities between both countries and how have they affected financial performance?

- Have some stakeholders benefited to a greater extent than others?

- What wider lessons can be learned?

Preliminary results show that these contracts continue to be very expensive for public administrations, especially in the UK, where the financing costs and fee per kilometre are high. On the other hand, they are an easy source of revenue for the parent companies, where the increased use of subordinated debt rather than equity seeks to reduce risk. However, some projects present poor outcomes, because, whilst they may appear to be well designed, location and/or forecast traffic volume may be poor. National characteristics are also important and can influence project performance and we consider the role of stakeholder management in relation to the DBFO policy. We identify a range of problems in evaluating the projects, including a lack of both ex ante and ex post transparency, and areas where additional costs are being incurred that contradict the rationale that using private finance will result in more efficient and cost-effective delivery and operations of projects. Nevertheless, the advantage of these projects is that the roads are freely available for all road users.

The paper is organised as follows. Section 2 provides a brief background and review of the literature on DBFO roads. Section 3 sets out the history and development of DBFO roads in the UK and Spain. Section 4 explains the methodology and research design. Section 5 presents the results. Section 6 discusses the results and Section 7 draws out the main conclusions.

\section{Background and literature review}

Transportation infrastructure has been the leading sector in which PPP has grown. According to the European PPP Expertise Centre (EPEC), since 1990, 1,100 
transportation projects with a value of $€ 282.2$ billion have been implemented in Europe, more than half of all PPP projects launched and more than 75 per cent of their value respectively. Within the transportation infrastructure sector, roads are also a testing ground in which governments have experimented with PPP. PPP toll roads are common world-wide, and have been relatively well studied (Acerete et al. 2009; Albalate et al. 2009; Baeza and Vassalloo 2010; Vasallo et al. 2011; Liyanage and Villalba-Romero 2015; Romboutsos 2016; World Bank 2017). Toll roads are examples of economic PPPs, which seek to deliver self-financing infrastructure projects. Less attention has been given to Long-Term Infrastructure Contracts (LTICs) such as DBFO road schemes, where the private sector builds or refurbishes the infrastructure and then operates and maintains it in return for government payments, whilst road users make no direct payments. These are examples of social infrastructure projects, that is, along with hospitals and schools, infrastructure which is regarded as a necessary part of the basic social welfare that should be delivered by the state.

Discussion of DBFO ex post operating performance in the PPP literature has been limited, with the only empirical evaluation of the financial performance of DBFO, being Shaoul et al. (2006), which found the cost to the public sector of using private finance to be very high over the first few years of operation. It is still not possible to examine whether these schemes deliver value for money for the public sector. Shaoul et al. (2006) noted there was no yardstick against which to measure value for money, as the cost of equivalent ex post public provision is not available. More recently the UK Public Accounts Committee (PAC, 2018) found it 'unacceptable' that after 25 years the UK Treasury still lacks data to show whether or not projects show value for money. There is a similar lack of any robust Spanish data.

Previous comparisons between the UK and Spanish operational performance of PPP roads have been limited and have not examined Spanish DBFO schemes (see for example Acerete et al. 2010) or the more recent UK schemes using availability payment mechanisms. Therefore, despite longstanding calls for better evaluation (Hodge and Greve 2007) there is still a lack of good and robust data and scheme evaluation (Verhoest et al. 2016). It is particularly notable that Spain was missing from Akintoye et al.'s (2016) global review of PPPs, although a number of relevant case studies feature in the publications coming out of the five-year COST Action TU 1001: PPPs in Transport study of 20 European countries (Roumboutsos 2016).

Two government payment mechanisms exist for DBFO roads projects, depending on how demand risk, that is, the number of vehicles using the road, is managed (Iossa 2015). Under the shadow toll payment mechanism, demand risk should transfer to the private operator as the public sector makes direct payments to the concessionaire based on the volume of traffic using the road. Under the availability payment mechanism, demand risk remains with the public sector and the concessionaire is paid for making the road available for public use. Contracts agreed under both mechanisms may have additional components, for example, shadow toll contracts often have a penalty element for substandard performance, whilst availability mechanisms may include incentives based on volume of traffic.

The UK began a DBFO programme using a shadow toll mechanism (Shaoul et al., 2006), with the first contract signed in 1996. This programme sought to solve the politically controversial problem of hard-tolling by providing what were badged as value 


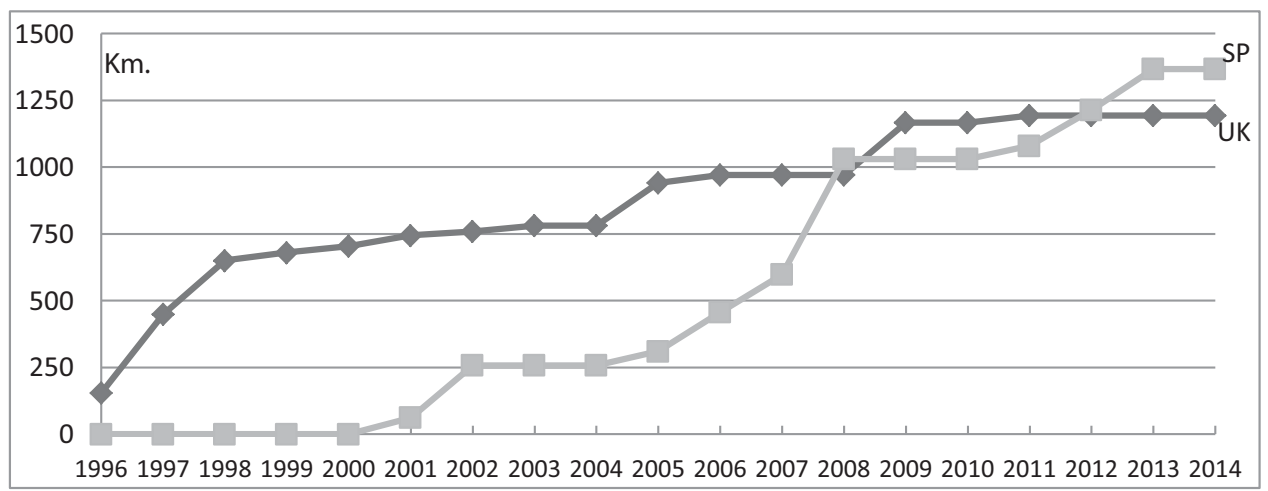

Figure 1 - Length of DBFO road schemes network in the UK and Spain.

Source: Own elaborated based on Spanish concessionaires' notes to the annual accounts and UK Treasury PFI spreadsheet.

for money contracts where the taxpayers rather than direct users paid the usage costs. Although Spain had a long experience with direct toll roads, it mimicked the UK shadow toll model a few years later in 1999, overtaking the UK in 2012 in terms of the number of kilometres of shadow toll schemes (see Figure 1). A small number of other countries have experimented with shadow toll roads programmes. Portugal contracted seven shadow toll schemes between 1999 and 2001 as part of its intensive expansion of its highways network. However between 2008 and 2010, the payments for these shadow toll roads doubled from $€ 400$ million to nearly $€ 900$ million (DGTF 2012). Given that Portugal was forced to apply for IMF bailout as a result of the financial crisis, this financing model was not sustainable (Cruz et al. 2015). Instead the schemes were converted to direct toll roads, with revenue going to the public sector which pays the concessionaires on the basis of an availability mechanism. Information on any other shadow toll schemes is sparse - Iossa (2015) reports that Finland has examples but gives no details. Liyanage et al. (2016) provides a brief case study of the Belgian Via-Invest Zaventem shadow toll project), finding that the cost of the project exceeded the budget, there are poor monitoring mechanisms and there is a lack of financial benefits for users. They do not report on the operating financial performance.

The UK also uses the availability payment mechanism, as well as having two contracts using a performance mechanism (known as Active Management). More countries have adopted the availability payment form of DBFO/DBFOM project, with examples in Canada, the US, Ireland (seven), the Netherlands and Australia amongst others.

Abdel (2007) provides an early overview of six Canadian DBFOM projects which included three roads. These projects contain a mixture of different types of payment mechanism, where, although the majority element is for availability there are adjustments for usage, safety, user satisfaction and quality amongst others. Some projects also include a capital payment. Although no overall evaluation is made, conclusions suggest that hybrid mechanisms including capital payments may offer the best outcome. Over the past decade the US has become interested in using PPPs to save cost on highway maintenance and refurbishment of its transport infrastructure. Two quantitative studies (Anastasopoulos et al. 2014; Nahidi et al. 2017) find a large number of factors are 
important in determining accurate costs at the planning stage, including project cost, size, duration and length, and call for further systematic work to identify what PPP models would best suit which type of projects.

Villalba-Romero and Liyanage (2015) provide a fuller qualitative case study of UK's M80 Haag Stepps Road and A19 Dishford Road, along with a study of the M25, in a paper comparing different payment mechanisms. They find that while there are benefits and drawbacks to each method, and that careful specification is needed, they are all useful. They suggest further study is needed to see if hybrid financing methods are appropriate.

\section{UK and Spanish DBFO schemes}

\subsection{Organisational structure}

In the UK, the DBFO company is a special purpose vehicle (SPV) whose shareholders are typically a construction company and one or more finance entities. Shareholders tend to be large international groups although there are some exceptions. In recent years a secondary market has developed for selling stakes in the SPV to private equity companies. The DBFO contract provides the SPV with its sole source of income that arises from the relevant payment mechanism: volume traffic basis (shadow toll), availability basis or active management. It must be highlighted that unlike the Spanish concessionaires the UK SPV is a shell company employing no staff. This corporate structure serves to isolate the SPV's risk, by enabling it to walk away from financial problems, while at the same time creating additional sources of profit for the parent companies (Acerete et al. 2010). All operations are carried out by the staff of related party companies. Parent companies include construction companies and financiers, and it is not possible to track profits through the web of related party companies, as construction, operation and maintenance activities are subcontracted out by the SPV, each activity having its own profit stream (Shaoul et al. 2010).

The Spanish concessionaires are subsidiaries (around $80 \%$ of the share capital) of the major Spanish construction and infrastructure construction-management companies that are world leaders in developing transportation concessions. ${ }^{1}$ Traditionally these companies have been successful in delivering good returns to investors through their integration of construction, concession and investor functions in a single company (Carpintero 2011). The remaining percentage is held by local construction companies as, unlike the Spanish hard-toll motorways, these are projects of regional interest. Like their UK counterparts however, more recently construction companies have been selling their interests to international investment funds. Public administrations do not appear formally as shareholders of these concessionaires, but, when some of them were set up, part of the initial contribution of shareholders came from savings banks in which, until the recent reform of the Spanish bank sector, the autonomous regional governments had political control (Ysa et al. 2012; García-Cestona and Surroca 2008; Grifell-Tatjé 2011).

1 According to the latest Public Works Financing ranking of 'World's Largest Transportation Developers' all these 6 parent companies are within the top 12 positions. 
The concessionaires' only revenue is the income derived from the shadow tolls generated on a traffic volume basis. Spanish shadow toll concessionaires employ some 275 workers as administrative staff, technical staff and managers.

\subsection{Legal framework}

Within the UK's common law tradition, contract law, involving the informed consent of both parties, plays an important role. Whilst early UK PFI projects suffered due to poor contract specification by the public sector (Edwards et al. 2004), the UK Treasury has since adopted Standard Contracts which, although very lengthy, serve to protect public and private sector partners alike. These contain variation mechanisms to allow for changes to the contract, which at the same time ensure that the equity return on which the contract was bid is protected. Renegotiation is therefore possible; however as both parties have to agree to changes it has been costly to the public sector (Edwards et al. 2004; NAO 2008). The UK response to high costs on DBFO projects has been to move from shadow toll contracts, where the public sector had no control over costs in the face of increasing traffic volumes, to availability payment mechanisms where demand risk remains with the public sector and the contract is therefore cheaper.

In contrast, Spain's Napoleonic-code-law regime leads to a government-driven system (Arnedo et al. 2008). Spanish (shadow) toll road legislation is governed by Ley 8/1972 de construcción, conservación y explotación de autopistas de peaje en régimen de concesion, if the public grantor modifies the project unilaterally, the concessionaire must be compensated to maintain the economic and financial balance. In addition, in accordance with the legislation concerning public sector contracts, concessionaires have the right to maintain the economic balance of the contract due to other circumstances, although these are not specified and depend on the terms included in the specific administrative clauses of the contract. As a result, 14 out of the 26 projects have modified their initial terms of contracts and 5 more have requested to do so.

Advantages awarded to concessionaires to maintain the economic-financial balance of the contract due to increases in investment works, compulsory purchases or delays in execution of works, regardless who, public administration or private operator, is responsible for them, are in the form of extension of the period of concession (3 projects) or modification (increase) of fees and toll bands (6 projects). But, the most widely used compensation has been the awarding of direct grants to concessionaires (15 projects), totalling some $€ 386$ million. In fact, five different grants have been awarded to the same project for different reasons, such as: increase in construction costs, compensation for the delay in coming into service, higher value of expropriations (twice) and to increase the IRR of the project. Besides, the average elapsed time since the signature of the contract for re-establishing its economic-financial balance is 4 years and 3 months, but, the average elapsed time reduces to 1 year and 4 months if we consider the date of opening of the road. The outcome is that this is very costly to the public administrations.

\section{$3.3 \quad$ Financing}

As to be expected with project financing, Table 3 shows the very high level of gearing for these DBFO contracts, rising from 93.1 to 98.7 per cent for the UK between 


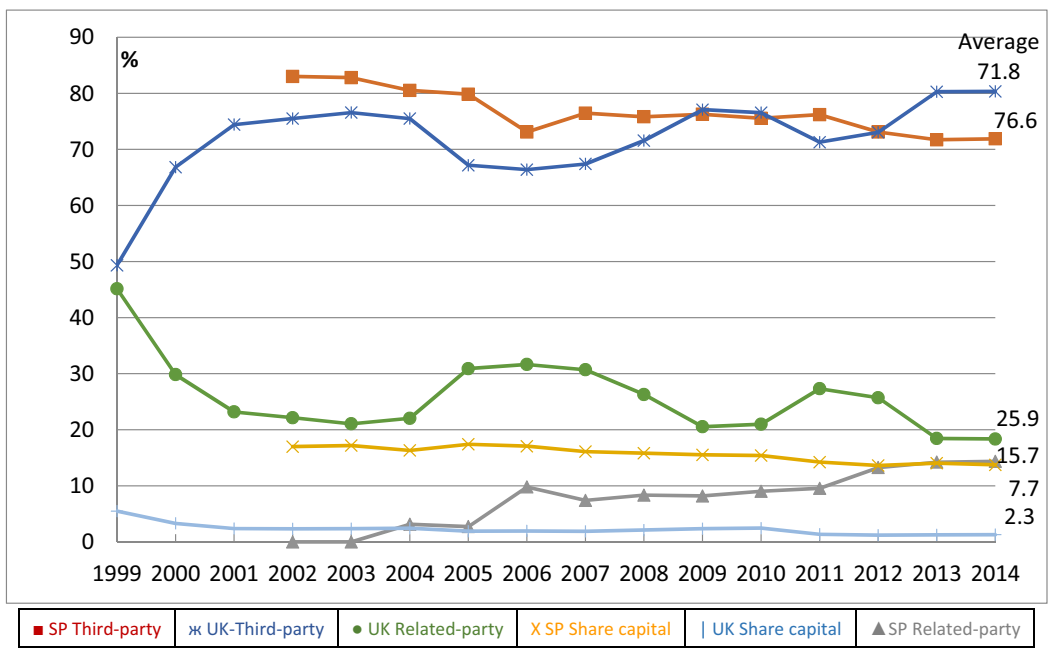

Figure 2 - Sources of finance. [Colour figure can be viewed at wileyonlinelibrary.com] Source: Own elaborated based on concessionaires' notes to the annual accounts. The figure at the end of the line is the average for the corresponding magnitude.

1999 and 2014, and from 83 per cent in 2002 to 86.3 per cent in 2014 for Spain. The main source of financing is third-party loans, as shown in Figure 2, with Spain showing a slightly higher average at 76.6 per cent than the UK's 68.1 per cent. What is interesting is the movement over time in loans from related parties. Whilst these have always been a substantial percentage for the UK, averaging 25.9 per cent, in Spain these have risen dramatically from zero at the start to 14.4 per cent in 2014, overtaking equity capital to become the second source of finance in 2013. This related-party financing comes mainly from subordinated debt borrowed by the parent company at a higher rate of interest than third-party debt due to its more risky nature. However Spain's equity capital proportion (15.7\% on average) continues to be much higher than the UK, where share capital has always had a residual role in financing DBFO schemes, averaging 2.3 per cent over the period. Table 4 shows the breakdown of sources of finance for 2014 . This historic difference in how projects are financed makes the comparison of stakeholder risk between the two countries analytically complex. It is notable however that following the banking and finance reforms in Spain, project finance is moving more towards the UK model where financiers seek to limit their risk through a variety of mechanisms, including transferring risk to sub-contractors or to the public sector, and spreading risk through activities including insurance, syndication and hedging (Demirag et al. 2011). The financial crisis had a further impact on financing, as financiers became more risk averse, leading to increased equity stakes in the UK as a consequence (Demirag et al. 2011), and in Spain to more regional government grants to concessionaires.

\subsection{Economic performance}

The UK presents a patchy position. Whilst most contracts have been very profitable for the operators, with 70 per cent paying dividends so far, three have had losses in all the years in operation. whilst another has become profitable but has not yet compensated 
brought forward losses. Spain's overall performance, unsurprisingly given the impact of the financial crisis at a key point when many contracts were becoming operational, is much worse. Only eight concessionaires have paid dividends (30\%), all but one of these being open to traffic before the economic crisis arose. The same number, eight out of the sample (30\%), have had losses throughout all the years they have been open to traffic and four more have not yet compensated for the accumulated brought forward losses (15\%). Overall therefore, there is distinctive difference between the UK and Spain. The UK SPVs have on the whole delivered solid returns to their investors and financiers, whilst the Spanish companies have proved to be far riskier operations for their investors, although as later sections show there has been significant government support that has been beneficial to these stakeholders.

\section{$4 \quad$ Research design}

Our aim is to carry out an ex post longitudinal comparative evaluation of UK and Spanish DBFO projects. Consequently we compare two groups of companies: UK DBFO road-operators and Spanish shadow toll-road operators. The sample is made up of the 19 UK and 26 Spanish concessionaires listed in Tables 1 and 2.

For UK DBFO companies we obtained the annual accounts from Companies House for the period 1999-2014, when the first roads had entered a steady state position. Similarly we accessed the Spanish concessionaires' annual accounts in the Registrar of Companies for 1999-2014, although we have analysed only data since the first complete year in which the first roads were open to traffic (2002). It was not possible to collect data from the public sector partner for either jurisdiction. In the UK this information is aggregated across contracts (Shaoul et al. 2010). In Spain the absence of a public unit, in which the information about these projects (annual payments, contract modifications, etc.) is centralised must be noted. Information about Spanish shadow toll projects is scattered in official regional gazettes, in the news or in reports of Spanish regional audit offices that normally are issued several years later than the period of performance under investigation; information is thus fragmented and not consistently provided.

We aggregate the concessionaires' financial data for each of the Spanish and the UK DBFO concessions. Given that the amount of payments from the public administrations is not available, we use the turnover given in the Income Statement of DBFO concessionaires. This figure is important because it allows us to see the scale of public money taken up by the DBFO schemes in total.

We split providers of finance into 'third party' and 'related-party' because parent companies and other related-party entities are increasingly not a marginal but a growing and relevant source of finance. As regards resources for financing the investment of concessionaires in the underlying asset we have only considered long-term resources for two reasons: firstly, to keep with the 'golden rule' of investment that states that long-term investments must be financed with long-term resources, so the demand of money for paying them back and the interests is in accordance with the realisation period of assets, secondly, because the short-term resources are immaterial in that they only represent 3 per cent of funds. 
Table 1 - UK DBFO schemes

\begin{tabular}{|c|c|c|c|c|c|c|}
\hline Project name & $\begin{array}{l}\text { Public ad- } \\
\text { ministration }\end{array}$ & $\begin{array}{l}\text { First date of } \\
\text { Operations }\end{array}$ & $\begin{array}{l}\text { Period of } \\
\text { contract }\end{array}$ & $\begin{array}{c}\text { Capital value } \\
(£ \mathrm{~m})\end{array}$ & $\begin{array}{l}\text { Length of } \\
\text { road }(\mathrm{km})\end{array}$ & $\begin{array}{l}\text { Type of } \\
\text { payment }\end{array}$ \\
\hline $\begin{array}{l}\text { A417/A419 } \\
\text { Swindon to } \\
\text { Gloucester }\end{array}$ & ENGLAND & 1996-04-01 & 30 & 110 & 52 & $\begin{array}{l}\text { Volume of } \\
\text { traffic }\end{array}$ \\
\hline $\begin{array}{c}\text { A30/A35 Exeter to } \\
\text { Bere Regis }\end{array}$ & ENGLAND & $1996-07-01$ & 30 & 75 & 102 & $\begin{array}{l}\text { Volume of } \\
\text { traffic }\end{array}$ \\
\hline $\begin{array}{l}\text { A19 Dishforth to } \\
\text { Tyne Tunnel } \\
\text { DBFO }\end{array}$ & ENGLAND & $1997-02-24$ & 30 & 29 & 118 & $\begin{array}{l}\text { Volume of } \\
\text { traffic }\end{array}$ \\
\hline $\begin{array}{l}\text { A69 Carlisle to } \\
\text { Newcastle }\end{array}$ & ENGLAND & 1997-05-01 & 30 & 9 & 87 & $\begin{array}{l}\text { Volume of } \\
\text { traffic }\end{array}$ \\
\hline $\begin{array}{l}\text { Autolink } \\
\text { Concessionaires } \\
\text { M6 }\end{array}$ & SCOTLAND & $1997-07-29$ & 30 & 96 & 90 & $\begin{array}{l}\text { Volume of } \\
\text { Traffic }\end{array}$ \\
\hline $\begin{array}{l}\text { A50/A564 Stoke to } \\
\text { Derby Link }\end{array}$ & ENGLAND & 1998-03-01 & 30 & 21 & 57 & $\begin{array}{l}\text { Volume of } \\
\text { traffic }\end{array}$ \\
\hline $\begin{array}{l}\text { A1(M) Alconbury to } \\
\text { Peterborough }\end{array}$ & ENGLAND & 1998-10-01 & 27 & 128 & 22.3 & $\begin{array}{l}\text { Volume of } \\
\text { traffic }\end{array}$ \\
\hline $\begin{array}{l}\text { M40 Denham to } \\
\text { Warwick }\end{array}$ & ENGLAND & $1998-12-01$ & 30 & 65 & 122 & $\begin{array}{l}\text { Volume of } \\
\text { traffic }\end{array}$ \\
\hline $\begin{array}{l}\text { M1-A1 Lofthouse to } \\
\text { Bramham Link }\end{array}$ & ENGLAND & 1999-02-01 & 30 & 214 & 30 & $\begin{array}{l}\text { Volume of } \\
\text { traffic }\end{array}$ \\
\hline $\begin{array}{l}\text { A13 Thames } \\
\text { Gateway DBFO } \\
\text { Contract }\end{array}$ & ENGLAND & $2000-07-11$ & 30 & 230.4 & 24 & Availability \\
\hline UK Highways A55 & WALES & 2001-03-16 & & 100 & 40 & $\begin{array}{l}\text { Volume of } \\
\text { traffic }\end{array}$ \\
\hline A130 & ENGLAND & 2002-02-01 & 29 & 97.5 & 15 & $\begin{array}{l}\text { Volume of } \\
\text { traffic }\end{array}$ \\
\hline $\begin{array}{l}\text { A1 Darrington to } \\
\text { Dishforth }\end{array}$ & ENGLAND & 2003-05-01 & 33 & 245 & 22 & $\begin{array}{l}\text { Active man- } \\
\text { agement }\end{array}$ \\
\hline $\begin{array}{l}\text { M77 (* including } \\
\text { Glasgow } \\
\text { Southern Orbital) }\end{array}$ & SCOTLAND & 2005-05-02 & 30 & 135 & 16.4 & Availability \\
\hline Angus A92 & SCOTLAND & $2005-09-30$ & 30 & 61.5 & 143.4 & $\begin{array}{l}\text { Volume- } \\
\text { availability }\end{array}$ \\
\hline $\begin{array}{l}\text { A249 Stockburyto } \\
\text { Sheerness }\end{array}$ & ENGLAND & 2006-07-01 & 30 & 73 & 30 & $\begin{array}{l}\text { Active man- } \\
\text { agement }\end{array}$ \\
\hline M25 Orbital & ENGLAND & 2009-09-01 & 30 & 988.1 & 195.5 & Availability \\
\hline $\begin{array}{l}\text { Carlisle Northern } \\
\text { Development } \\
\text { Route }\end{array}$ & ENGLAND & 2011-08-10 & 30 & 60.1 & 8.3 & Availability \\
\hline $\begin{array}{l}\text { M80 Stepps to } \\
\text { Haggs }\end{array}$ & SCOTLAND & 2011-09-09 & 31 & 320 & 18 & Availability \\
\hline
\end{tabular}

Source: UK HM Treasury PFI Current Projects Spreadsheet available at: https://www.gov.uk/government/ publications/private-finance-initiative-and-private-finance-2-projects-2017-summary-data

In Spanish companies, the financial expenses payable to third party finance providers interests include both financial expenses taken to the Income Statement and capitalised interests that have accrued but where recognition in the Income Statement can be deferred, according to the specific variation of the Spanish General Accounting Plan for the concession sector (Stafford et al. 2010). Also in Spain, the annual allocation 
Table 2 - Spanish shadow toll projects

\begin{tabular}{|c|c|c|c|c|c|}
\hline Project name & $\begin{array}{l}\text { Autonomous } \\
\text { region }\end{array}$ & $\begin{array}{l}\text { First day of } \\
\text { operations }\end{array}$ & $\begin{array}{c}\text { Operational } \\
\text { period of contract } \\
\text { (years) }\end{array}$ & $\begin{array}{c}\text { Capital value } \\
\text { (€million) }\end{array}$ & $\begin{array}{l}\text { Length of road } \\
\qquad(\mathrm{km})\end{array}$ \\
\hline $\begin{array}{c}\text { AUTOVÍA DEL } \\
\text { NOROESTE }\end{array}$ & Murcia & $2001-12-10$ & 25 & 96.3 & 62.2 \\
\hline $\begin{array}{c}\text { RUTA DE LOS } \\
\text { PANTANOS }\end{array}$ & Madrid & $2002-09-27$ & 25 & 69.9 & 159 \\
\hline TRADOS 45 & Madrid & 2002-03-14 & $\begin{array}{l}25 \text { (extended } 51 \\
\text { months) }\end{array}$ & 190.9 & 14.5 \\
\hline EUROGLOSA 45 & Madrid & 2002-03-14 & $\begin{array}{c}25 \text { (extended } 50 \\
\text { months) }\end{array}$ & 86.7 & 8.3 \\
\hline $\begin{array}{c}\text { CONCESIONES } \\
\text { DE MADRID }\end{array}$ & Madrid & 2002-03-14 & $\begin{array}{c}25 \text { (extended to } \\
34)\end{array}$ & 191.5 & 14.2 \\
\hline $\begin{array}{l}\text { AUTOVÍA DE LA } \\
\text { MANCHA }\end{array}$ & $\begin{array}{r}\text { Castile-La } \\
\text { Mancha }\end{array}$ & $2005-05-28$ & 30 & 123.8 & 52.3 \\
\hline $\begin{array}{l}\text { AUTOVÍA DE } \\
\text { LOS VIÑEDOS }\end{array}$ & $\begin{array}{r}\text { Castile-La } \\
\text { Mancha }\end{array}$ & 2006-05-01 & $25-30$ & 200.1 & 74.5 \\
\hline $\begin{array}{l}\text { AUTOVÍA DEL } \\
\text { CAMINO }\end{array}$ & Navarre & 2006-06-30 & 30 & 354.6 & 72 \\
\hline $\begin{array}{l}\text { PALMA- } \\
\text { MANACOR }\end{array}$ & Balearic Islands & 2007-01-01 & $\begin{array}{l}33 \text { (extended } 5 \\
\text { years and } 4 \\
\text { months) }\end{array}$ & 117.3 & 43.7 \\
\hline MADRID 407 & Madrid & $2007-05-03$ & 30 & 70.3 & 16 \\
\hline VIASTUR & Asturias & $2007-05-13$ & 30 & 72.5 & 26.8 \\
\hline IBISAN. & Balearic Islands & $2007-06-30$ & 30 & 75.6 & 17.5 \\
\hline EIXLLOBREGAT & Catalonia & 2008-01-01 & 33 & 311 & 40 \\
\hline $\begin{array}{l}\text { SANTIAGO- } \\
\text { BRIÓN }\end{array}$ & Galicia & 2008-02-15 & 30 & 111.1 & 15 \\
\hline REUS ALCOVER & Catalonia & $2008-06-13$ & 33 & 80 & 10.2 \\
\hline $\begin{array}{l}\text { PUENTE DEL } \\
\text { EBRO }\end{array}$ & Aragon & 2008-07-04 & 30 & 57.2 & 5.2 \\
\hline $\begin{array}{l}\text { ACCESOS DE } \\
\text { IBIZA }\end{array}$ & Balearic Islands & $2008-07-15$ & 25 & 74.9 & 7 \\
\hline $\begin{array}{l}\text { AUTOVÍA DEL } \\
\text { TURIA }\end{array}$ & Valencia & $2008-07-31$ & 36 & 161.2 & 54 \\
\hline $\begin{array}{l}\text { AUTOESTRADA } \\
\text { DO SALNES }\end{array}$ & Galicia & $2008-08-23$ & 30 & 53.6 & 17 \\
\hline $\begin{array}{c}\text { AUTOVÍA DEL } \\
\text { ERESMA }\end{array}$ & Castile and León & 2008-09-19 & 35 & 101.8 & 113 \\
\hline $\begin{array}{l}\text { AUTOVÍA DE } \\
\text { LOS PINARES }\end{array}$ & Castile and León & 2008-09-24 & 35 & 94 & 104.6 \\
\hline $\begin{array}{r}\text { AUTOVÍA DEL } \\
\text { BARBANZA }\end{array}$ & Galicia & $2008-12-15$ & 30 & 95.7 & 40.1 \\
\hline CEDINSA D'ARO & Catalonia & $2008-12-31$ & 33 & 88.3 & 27 \\
\hline CEDINSA TER & Catalonia & 2011-07-31 & 33 & 348 & 49 \\
\hline $\begin{array}{c}\text { AUTOVÍA DEL } \\
\text { PIRINEO }\end{array}$ & Navarre & 2012-01-15 & 30 & 219.3 & 67.3 \\
\hline $\begin{array}{l}\text { EIX DIAGONAL } \\
\text { CONCES- } \\
\text { SIONARIA }\end{array}$ & Catalonia & $2012-12-28$ & 33 & 475 & 67 \\
\hline
\end{tabular}

Source: Own elaboration based on Notes to the annual accounts of concessionaires. 
Table 3 - Gearing ratio

\section{GEARING}

RATIO 2014201320122011201020092008200720062005200420032002200120001999

\begin{tabular}{lcccccccccccccccc}
\hline SP & 86.3 & 86 & 86.4 & 85.8 & 84.6 & 84.5 & 84.2 & 83.9 & 82.9 & 82.6 & 83.7 & 82.8 & 83 & - & - & - \\
UK & 98.7 & 98.7 & 98.7 & 98.5 & 97.2 & 97.3 & 97.6 & 97.9 & 97.8 & 97.8 & 97.1 & 97.2 & 97.2 & 97.2 & 96.2 & 93.1 \\
\hline
\end{tabular}

Table 4 - Sources of finance (2014)

\begin{tabular}{lccccc}
\hline & \multicolumn{2}{c}{ UK } & & \multicolumn{2}{c}{ SP } \\
\cline { 2 - 3 } & Emillion & \% over total capital & & Emillion & \% over total capital \\
\hline INVESTMENT (gross) & 3,295 & & 3,556 & \\
L/T DEBTS WITH THIRD PARTY & 2,160 & 79.6 & & 2,748 & 71.9 \\
L/T DEBTS WITH RELATED-PARTY & 518 & 19.1 & & 549 & 14.4 \\
SHARE CAPITAL & 36 & 1.3 & & 525 & 13.7 \\
TOTAL CAPITAL EMPLOYED & 2,714 & & & 3,822 & \\
\hline
\end{tabular}

to a 'Special Motorways Reserve' has been added to the Dividends item, because this reserve is specifically allocated to be used in the case that dividends paid in a year do not reach 6 per cent of return to shareholders.

We calculate ratios showing and comparing the return to the providers of both debt and equity. The return on debt also distinguishes between the interest paid to third-party finance providers and to related-party entities, because DBFO arrangements have created a finance market opportunity for parent companies, since they provide subordinated debt to the DBFO subsidiaries. In both cases, the UK and Spain, debt includes derivatives used by companies to reduce the cost of third-party financing. The return for each stakeholder is measured as follows:

- Third-party finance providers $\approx$ Interest paid/Long-term finance liabilities of third parties

- Related-party finance providers $\approx$ Interest paid/Long-term finance liabilities of related parties

- Shareholders $\approx$ Dividends/Share capital

- Total return $\approx$ (Dividends + Interest) / (Share capital + Long-term finance liabilities)

The difference between the return on private finance and the cost of public finance allows us to understand the cost of using DBFO arrangements compared to traditional procurement. We measure the difference between the cost of private and public finance by comparing the average return to private finance providers to the yield of a 30 -year bond issued by the Spanish and the UK ( 30 years is the most common length of DBFO contracts). The difference between the two approximates to the price paid for risk 


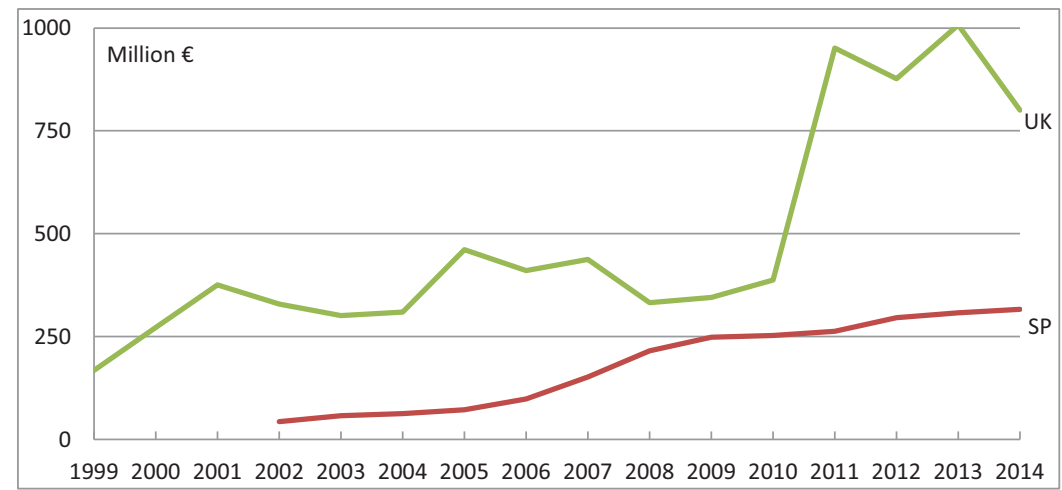

Figure 3 - Evolution of turnover in the UK and SP DBFO concessionaires. [Colour figure can be viewed at wileyonlinelibrary.com]

Source: Own elaborated based on concessionaires' notes to the annual accounts. The conversion of the Turnover of UK companies into $€$ is done using the official exchange rate $€ / £$ at the balance sheet date.

transfer to the private operators, the return on finance provided also by the private operators and the return on equity for the private operators.

In order to compare monetary data for the two countries we have chosen to present figures in Euros, rather than UK sterling. The movement in exchange rates over the period has led to income increases in favour of the UK DBFO concessionaires, even though sterling depreciated up to $50 \%$ during this period. However the trend of increases in payments by the public administrations is higher than the decrease of the currency value.

\section{$5 \quad$ Financial analysis}

This section presents the results of our financial analysis. We use a graphical presentation so that the trends and movements for both countries over the 15 year period can easily be seen.

\subsection{Analysis of DBFO concessionaires' turnover}

Although the length of the DBFO road network has been similar since 2008, and has been longer in Spain than the UK since 2012, the overall Turnover of the DBFO sector in the UK has been always much higher than in Spain (see Figure 3). In part this is due to underestimation of traffic volume in the UK compared to over-estimation in Spain (Bain 2009). Whereas the Turnover of the Spanish concessionaires have had an steady increase throughout the period, in line with the increase of the kilometres open to traffic, UK income increase is not linear due to the accounting treatment which sees the asset under construction being transferred as 'turnover' in the income statement when the asset reached completion. So the 'peaks' that appear in Figure 3 are due to the recognition of asset construction cost as income by concessionaires of the termination 

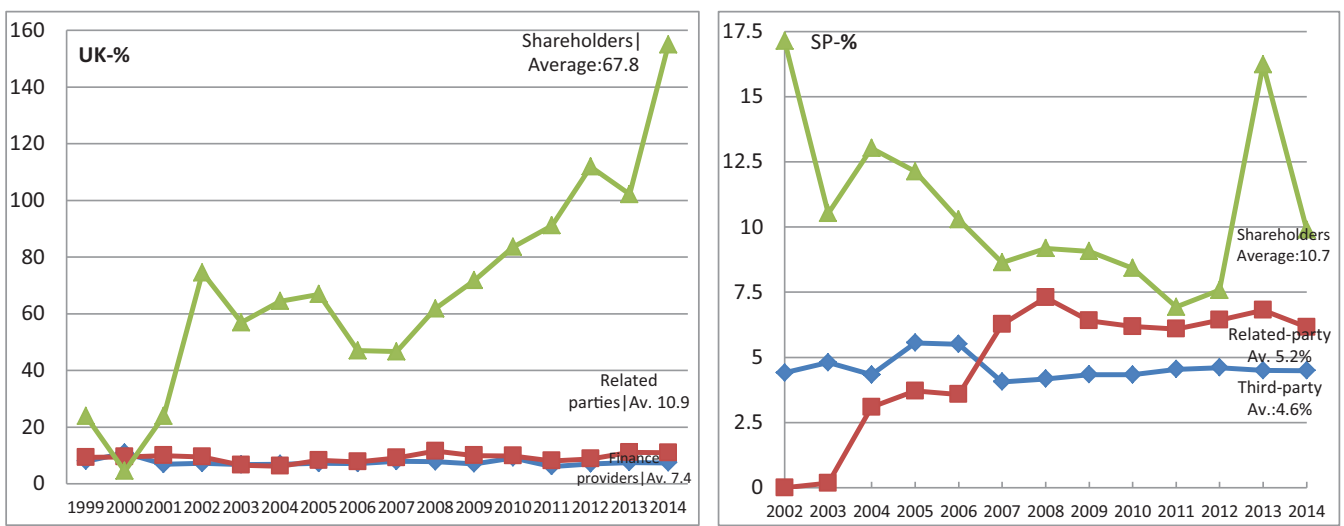

Figure 4 - Return to DBFO finance providers (as \% of the corresponding magnitude over the corresponding finance item). [Colour figure can be viewed at wileyonlinelibrary.com]

of the road works and its delivery to public use. The opening in 2012 of the M25, the biggest DBFO contract in the UK, hugely distorts the data of the latest years of the sample period, because it represents more than 34 per cent of the total investment in UK DBFO roads.

\subsection{Return on investment to stakeholders}

Figure 4 shows the return on investment to stakeholders. For Spanish concessions, the shareholders are the clear winners, with an average return of 10.7 per cent, followed by related-party finance providers with 5.2 per cent and third-party finance providers with 4.6 per cent. However the returns to shareholders show a continuous decrease over time, due to the increase of the total share capital as new concessionaires join the sector, but no more concessionaires pay dividends. Since 2007 the returns to related-party providers have superseded the returns to external finance providers.

As already noted, the UK's shareholders contribute little resources in financing the investment, but they obtain a high return on their investment, for instance an average return of 67.8 per cent, reaching a peak of 157 per cent in 2014. In Spain, related-party finance providers have obtained an average return that is also higher than third-party finance providers, 10.9 per cent vs. 7.4 per cent. In percentage and absolute terms, the returns to DBFO stakeholders are much higher in all the groups in the UK than in Spain, especially in the case of shareholders.

\subsection{Comparison between private and public finance cost in DBFOs}

As expected, Figure 5 shows the cost of private finance for Spanish DBFO schemes to be more expensive than the equivalent finance provided by public administrations, 5.5 per cent vs. 5.1 per cent. But during years 2010, 2011 and 2012 the cost of public debt was nearly equal or even higher than the cost of private finance resources. The reason for this apparent failure to comply with economic theory is that during these 


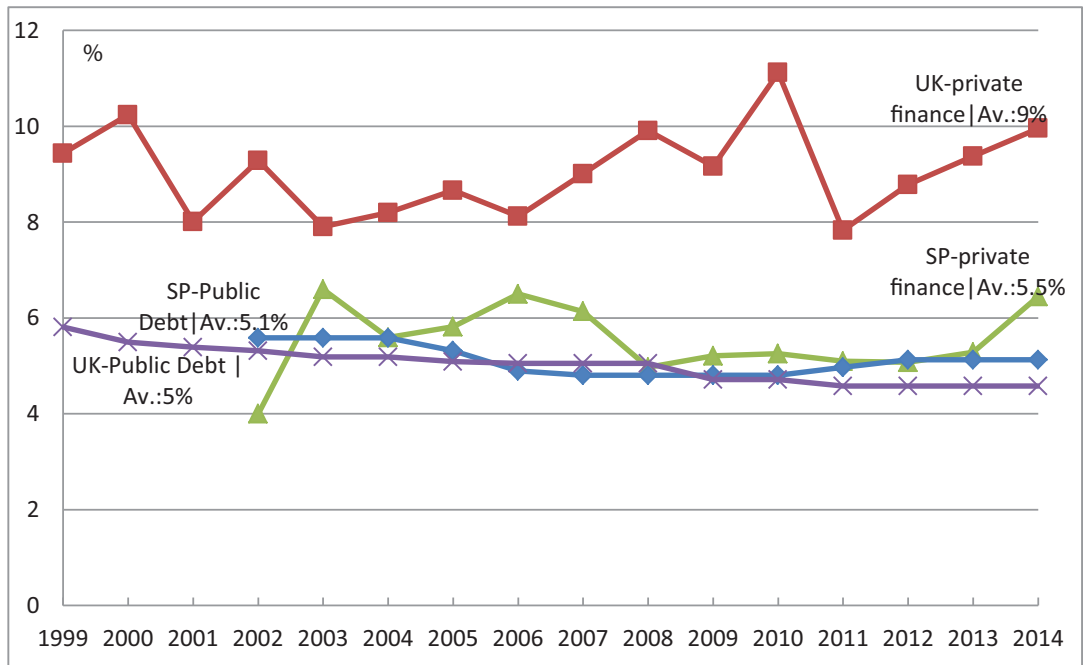

Figure 5 - Private and public finance cost of DBFO projects. [Colour figure can be viewed at wileyonlinelibrary.com]

years, Spain was on the verge of being rescued, in fact several Spanish banks were placed in administration and the risk premium paid by Spanish public administration was over 600 basic points (it has since fallen to around 100 basic points), so it was not impossible that under these conditions public debt continued being cheaper than private finance.

The average cost of private finance for UK DBFO schemes in the period 1999-2014 is more than twice higher than the equivalent finance provided by public administrations, 9 per cent vs. 4 per cent. While private finance cost follows a slight upward trend, the public debt cost follows a downward trend, so difference in cost of the two sources of finance seems set to diverge still further in the near future. If we compare the total percentage of return to finance providers, we can see that the UK return is 3.5 per cent percentage points (about 40\%) higher in the UK than in Spain (see Figure 5). Private finance is more expensive in the UK than in Spain, whereas public cost of financing has been slightly cheaper in the UK than in Spain.

\section{Discussion}

We examine a number of issues and limitations that arise from our evaluation of UK and Spanish DBFO contracts over the long term. Our analysis of financial performance shows that there are some structural differences between the UK and Spain in relation to DBFO roads contracts, making the comparison problematic. The UK financing model from the start has been more debt-dependent than the Spanish model, the cost of private finance has been much higher compared to the cost of public debt, and early UK schemes in particular have been very profitable for the private sector equity partner (Shaoul et al. 2006, 2012). In contrast Spanish schemes have had greater 
shareholder participation, and follow the concessionaire model with which Spain has been familiar since initiating a hard toll road programme in the 1960s. Since the financial crisis however, Spain's financing model seems to be moving more towards the UK model, which may be as a consequence of the commercialisation of the Spanish banking system (Ysa et al. 2012, Acerete et al., 2015). Spanish financial performance has worsened since the financial crisis, making our analysis extremely difficult due to the extensive and long-running succession of losses being recorded.

Our empirical work highlighted a range of issues which reflect global concerns around the use and implementation of PPP policies. First, there continues to be a lack of transparency as to how governments make the decision to use PPPs, or particular models of PPPs. In Spain, where there is no requirement to put forward a justification based on a Value For Money case, several regional public audit offices have denounced the lack of reports justifying the election of the PPP alternative. For example, in 2005 the Regional Audit Office of Madrid said:

The autonomous government has not provided any previous viability report, including the cost of the investment to be done and the financing scheme, as well as the justification of the chosen scheme.

A decade later we found a similar statement from the Regional Audit Office of Andalusia:

...there is not any analysis or any information stating if when the decision for choosing the concessional model as public-private partnership scheme for carrying out new infrastructure was made, other alternative schemes were evaluated.

In the absence of official reports, the Regional Audit Office of Andalusia carried out a simulation and the PPP alternative was significantly more expensive that the traditional public procurement (between 70 and 83\%) than the traditional public procurement. It has to be noted that these figures do not include the estimated impact of risk transfer linked with the PPP alternative or the opportunity cost of bringing together the budgetary funds with the traditional public procurement in a few years.

In the UK, the Value for Money calculation is an important part of the government process and must be followed. However, as noted earlier, there is still no robust evidence from the Treasury that value for money is being achieved in practice (NAO 2018; PAC 2018). Moreover there is silence as to why and when the government changed from using the shadow toll mechanism to the availability payment mechanism, or why a third mechanism of active management has been introduced for a small number of roads. The UK's National Audit Office (NAO) has not commented on this change. More work needs to be carried out to see if the projects using these alternative payment mechanisms are less expensive for the public sector.

Second, Spanish projects were permitted to go ahead due to excessively optimistic traffic volume forecasts. For some projects actual volume has ranged from 26 per cent to 40 per cent less than the forecast. Traffic volume forecasting is well known to be problematic in roads projects (Bain 2009), indicating that decisions to go ahead with projects were taken for political rather than economic reasons. This is consistent with earlier findings relating to UK DBFO roads where Acerete et al. (2010) 
Table 5 - Initial deviations in Madrid and Catalonia's projects

\begin{tabular}{llccr}
\hline & & $\begin{array}{c}\text { INITIAL INVESTMENT } \\
\text { (Million } € \text { ) }\end{array}$ & $\begin{array}{c}\text { FINAL INVESTMENT } \\
\text { (Million } € \text { ) }\end{array}$ & $\begin{array}{c}\text { Deviation } \\
(\%)\end{array}$ \\
\hline MADRID & TRADOS 45 & 199.2 & 290.7 & 45.9 \\
& EUROGLOSA 45 & 128.4 & 172.2 & 34.1 \\
& CONCESIONES DE MADRID & 168 & 290.7 & 73.0 \\
\multirow{5}{*}{ CATALONIA } & RUTA DE LOS PANTANOS & 138.9 & 169.9 & 22.3 \\
& CEDINSA EIX LLOBREGAT & 270.9 & 311.1 & 14.8 \\
& REUS-ALCOVER & 61 & 80 & 31.1 \\
& CEDINSA D'ARO & 85.7 & 88.4 & 3.2 \\
& CEDINSA TER & 245.9 & 348.4 & 41.7 \\
& EIX TRANSVERSAL & 805.6 & 946.2 & 17.5 \\
& EIX DIAGONAL & 463.6 & 476.5 & 2.8 \\
& AVERAGE & & & 28.6 \\
\hline
\end{tabular}

quoted from DLA Piper (2004) in saying that 'PPPs are dependent on a fourth 'P' politics'.

Third, the financial crisis had a huge impact on the cost of DBFO projects. In the UK, the contract to widen the M25 was severely criticised by the NAO (2010). An 18-month delay due to technical issues around creating an additional lane meant that it was finalised in May 2009 at the height of the financial crisis, thus increasing the net present cost by $£ 660 \mathrm{~m}(24 \%)$ to $£ 3.4 \mathrm{bn}$. In Spain the financial crisis and subsequent EU regulator implementation of tougher requirements for banks over-exposed to public administration projects made it difficult to find providers of finance. For one example, the Eix Diagonal, in Catalonia only two contractors were able to complete the financing offer in the tender. The winner, ACS, expected to get financial resources that amounted to 85 per cent of the investment, contributing the remaining 15 per cent ( $€ 18.5$ million) as equity. But, finally, equity was $€ 160$ million. In Galicia the project Costa da Morte was designed with a length of $42 \mathrm{~km}$., but the concessionaire did not found enough financing. There was a partial termination of the contract reducing the length of the motorway to $25 \mathrm{~km}$.

Fourth, although there are claims that PPPs are meant to deliver projects to cost, large cost overruns continue to occur. The NAO (2010) reported on cost problems in relation to the UK M25. In Spain Madrid and Catalonia have recorded on average deviations of 28 per cent and 41 per cent in the investment in the road and expected payments to the concessionaire, respectively (see Table 5). In Madrid projects were signed in 1998/1999 and in Catalonia in 2003/2009, so public administrations have not learnt how to deal with deviations by means of PPP. Furthermore, Galician shadow toll motorways have had price modifications between 9 and 29 per cent that have been covered with direct payments by the regional government, even though the regional audit office uncovered that these modifications related to construction risks that the concessionaire should bear or other matters that should have been solved before signing the contract (Consello de Contas de Galicia 2014).

Fifth, the use of a shadow toll payment mechanism is expensive. It does not represent value for money for the public sector, as within short time periods more than 
the full cost of the scheme is already paid, as reported by Shaoul et al. (2006) for the UK and as shown by concessions such as the Madrid M-45 scheme ${ }^{2}$ and Navarre's Autovía del Camino scheme, both of which repay the capital cost within 10 years of opening. Even though these figures incorporate amounts for life cycle costing, the capital payback time seems very short. Moreover the high costs have the potential to create affordability problems for public administration budgets. The lack of information provided, plus the uncertainty around payments based on traffic volumes which are not known in advance, means that total commitments are unknown. This would not happen if the infrastructure were financed via traditional public procurement ${ }^{3}$. In addition, shadow toll payments can weaken public administrations, because their investment capacity is diminished as their budget is conditional on these payments. Shaoul et al. (2006) note that the high cost of the first eight UK DBFOs creates an affordability issue for the (then) Highways Agency. In several Spanish regions shadow toll payments take up a significant portion of public budgets. In Asturias, the payments due to shadow toll contracts use 12.5 per cent of the budget of the Department of Public Works. In Galicia in 2011, the use of shadow toll represented some 38 per cent of the total investment. In Madrid, in 2011, despite the reduction of the overall budget of expenses about 10 per cent, the payments to shadow toll concessionaires increased 5.7 per cent with respect to the previous year. In Navarre, in 2015, 20.8 per cent of the budget for investments was dedicated to shadow tolls. In the Balearic Islands, the specific budget for roads in the island of Ibiza, in 2017, commits 68 per cent for paying shadow tolls. If there are also cuts in public budgets, as is the case in both countries due to austerity measures, then some public administrations may struggle to pay shadow toll commitments. This issue has been particularly acute in Spain. In Andalucía, two contracts were awarded, but later they were terminated due to the difficulties of concessionaires to formalise the finance of the project and also due to the economic situation of the Autonomous Government that anticipated affordability problems.

Finally, as has been the case with Spanish toll roads, where the PPP policy privatises the benefits and nationalises the losses (Acerete et al. 2010), a number of Spanish shadow toll concessionaires have received extra grants or other benefits from the respective regional governments. These include Cendinsa Ter, where the regional government of Catalonia will have to pay an additional net amount of $€ 80$ million on top of a previous assumption of debt of $€ 220$ million and equity of $€ 55$ million in 2015 . Similarly the Galician regional government rescued two concessionaires in 2008 and 2009 and in 2014 increased annual payments by $€ 7$ million, to avoid the payment of $€ 189$ million if these companies entered into bankruptcy, due to its patrimonial responsibility. Madrid has awarded direct grants of $€ 81.9$ million in addition to annual payments. This contrasts with the UK position, where rising traffic volume has meant shadow toll payments more than cover private sector operating costs. Instead in the UK the focus has been on whether the private sector is generating excessive returns. The UK PAC (2003) found

2 Our characterisation of the M-45 as very expensive contrasts with Liyanage et al. (2016) performance score of 83 per cent (excellent) in their study measuring success of a number of PPP roads projects. This is because their focus is on the financial outcome for the private, rather than the public, partner.

3 Audit report about the public private performance of the Public Works Agency of the Government of Andalusia, for the year 2013. 
that SPVs were generating between three and ten times as much as the perceived 'normal' rates of return of 8-15 per cent, whilst for the M25 it was estimated that investors' returns from selling their stakes were over 30 per cent, that is, more than double the expected return (NAO 2010).

In summary, our financial evaluation of shadow toll road performance in both countries favours the providers of finance and equity shareholders at the expense of the public sector. The public sector position has been worsened by additional costs imposed by the financial crisis, which creates a real threat to affordability when the position of DBFO roads is added to crises relating to PFI and PPP hospital contracts. The problems of lack of transparency over policy use and operational performance noted in previous studies (Shaoul et al. 2006; Acerete et al. 2010) continue to exist.

\section{Conclusions}

Whilst DBFO roads contracts have not received the same level of attention in the literature as toll roads, they still represent an important part of the Long Term Infrastructure Contracts family (Hodge et al. 2010). We seek to add to our understanding of how performance of these contracts has changed over the last ten years, whether a better balance between stakeholder returns is present and whether there is evidence of institutional learning from lessons raised in the past.

Whilst the UK and Spain are both leading players in DBFO contracts, there are jurisdictional differences in the way the two states approach these contracts and manage their PPP policy (Stafford et al. 2010). Consequently, there are differences in organisational structure, legal framework, financing and operations. This is a limitation for comparative study, as we are not able to compare like-with-like.

The UK has moved away from expensive shadow toll payment mechanisms to availability payment and active management mechanisms Further study of the financial performance of these newer contracts would be useful to put alongside case studies such as Villalba-Romero and Liyanage (2016) to discover if and/or how there are changes in how stakeholders' returns are balanced. In Spain, it is striking that Spanish regional public administrations continued to enter into shadow toll contracts for some time after other jurisdictions had moved to alternative payment mechanisms, particularly when one of these jurisdictions was its close neighbour Portugal, in whose DBFO projects Spanish construction companies have a relevant participation. Further study which draws on Norton and Blanco (2009) and Burke and Demirag (2017) in an examination of stakeholder relations could shed further light on why Spanish regions have persisted with shadow toll contracts.

Given the importance of roads infrastructure to economic development and the continuing global emphasis on the use of private finance to deliver such infrastructure, the debate continues over whether governments should use DBFO or hard toll contracts for PPP roads projects. Having a good understanding of the operational financial performance of existing contracts, the roles of the various stakeholders and the problems posed particularly for the public sector partner is essential if future contracts are to be affordable. 


\section{REFERENCES}

ABDEL AZIZ A. M., 2007, 'A survey of the payment mechanisms for transportation DBFO projects in British Columbia', Construction Management and Economics, 25, $529-543$.

ACERETE B., GASCA M., STAFFORD A. and STAPLETON P., 2015, 'A comparative policy analysis of healthcare PPPs: examining evidence from two Spanish regions from an international perspective', Journal of Comparative Policy Analysis, 17, 502-518.

ACERETE B., SHAOUL J. and STAFFORD A., 2009, 'Taking its toll: the private financing of roads in Spain', Public Money \& Management, 29, 19-26.

ACERETE B., SHAOUL J., STAFFORD A. and STAPLETON P., 2010, 'The cost of using private finance for roads in Spain and the UK', Australian Journal of Public Administration, 69, S48-S60.

AKINTOYE A., BECK M. and KUMARASWAMY M., 2016, Public-Private Partnerships: A Global Review, Oxford: Routledge.

ALBALATE D., BEL G. and FAGEDA X., 2009, 'Privatization and regulatory reform of toll motorways in Europe', Governance: An International Journal of Policy, Administration, and Institutions, 22, 295-318.

ARNEDO L., LIZARRAGA F. and SÁNCHEZ S., 2008, 'Discretionary accruals and auditor behaviour in code-law contexts: An application to failing Spanish firms'. European Accounting Review,17, 641-666.

BAIN R., 2009, 'Error and optimism bias in toll road traffic forecasts', Transportation, $36,469-482$.

BAEZA M.Á. and VASSALLO J. M., 2010, 'Private concession contracts for toll roads in Spain: analysis and recommendations', Public Money \& Management, 30, 299-304.

BURKE R. and DEMIRAG I., 2017, 'Risk transfer and stakeholder relationships in Public Private Partnerships', Accounting Forum, 41, 28-43.

CARPINTERO S., 2011. The competitive advantages of the Spanish companies in the international toll road industry. Journal of Civil Engineering and Management, 17, $483-493$.

CONSELLO DE CONTAS DE GALICIA, 2014, Informe de Fiscalización de la Cuenta General de la Administración - Ejercicio 2012, available at: http://parlamento. gal/sitios/web/BibliotecaConselloContasGalicia/161_D_Conta_Xeral_Admon_2012_C. pdf [accessed 26/08/2017].

CRUZ C. O., MARQUES R. C. and CARDOSO P., 2015, 'Empirical evidence for renegotiation of PPP contracts in the road sector', Journal of Legal Affairs and Dispute Resolution in Engineering and Construction, 7, 08014001.

DGTF (DIRECÇAO GERAL DO TESOURO E FINANÇAS), 2012, Relatório sobre Parcerias Público-Privadas e Concessões, available at: http://www.dgtf.pt/ ResourcesUser/PPP/Documentos/Relatorios/2012/Relatorio_Anual_PPP_2012.pdf

DEMIRAG I., KHADAROO I., STAPLETON P. and STEVENSON C., 2011. Risks and the financing of PPP: Perspectives from the financiers. The British Accounting Review, 43, 294-310. 
DLA PIPER, 2004, European PPP Report 2004.

EDWARDS P., SHAOUL J., STAFFORD A. and ARBLASTER L., 2004, Evaluating the Operation of PFI in Road and Hospital Projects (ACCA Research Report No 84), London: Association of Chartered Certified Accountants.

EUROPEAN PPP EXPERTISE CENTRE (EPEC), various years, Market Update: Review of the European PPP Market, available at: http://www.eib.org/epec [accessed May 23, 2017].

GARCÍA-CESTONA M. and SURROCA J., 2008, 'Multiple goals and ownership structure: Effects on the performance of Spanish savings banks', European Journal of Operational Research, 187, 582-599.

GRIFELL-TATJÉ E., 2011, 'Profit, productivity and distribution: Differences across organizational forms - The case of Spanish banks', Socio-Economic Planning Sciences, 45, 72-83.

HODGE G. A. and GREVE C., 2007, 'Public-private partnerships: an international performance review', Public Administration Review, 67, 545-558.

HODGE G. A., GREVE C. and BOARDMAN A., 2010, 'International handbook on publicprivate partnerships', Edward Elgar Publishing.

IOSSA E., 2015, 'Contract and procurement design for PPPs in highways: the road ahead', Economia e Politica Industriale, 42, 245-276.

LIYANAGE C. and VILLALBA-ROMERO F., 2015, 'Measuring success of PPP transport projects: a cross-case analysis of toll roads', Transport Reviews, 35, 140-161.

LIYANAGE C. et al., 2016, 'Measuring success in PPP road projects in Europe: A performance measurement system (PMS)', Chapter 15 in Roumboutsos, A. et al. (eds.), Public Private Partnerships in Transport: Trends and Theory. Cost Programme, London: Routledge.

NATIONAL AUDIT OFFICE (NAO), 2008, Making Changes in Operational PFI Projects, Report by the Comptroller and Auditor General, HC 205, Session 2007-08, January 2008, London: The Stationery Office.

NATIONAL AUDIT OFFICE (NAO), 2010, Highways Agency - Procurement of the M-25 Private Finance Contract, Report by the Comptroller and Auditor General, The Stationery Office, London, available at: http://www.nao.org.uk/wpcontent/uploads/2010/11/1011566.pdf.

NATIONAL AUDIT OFFICE (NAO), 2018, PFI and PF2, Report by the Comptroller and Auditor General, HC718, Session 2017-19, The Stationery Office, London

NORTON S. D. and BLANCO L., 2009, 'Public-private partnerships: a comparative study of new public management and stakeholder participation in the UK and Spain', International Journal of Public Policy, 4, 214-231.

PUBLIC ACCOUNTS COMMITTEE (2003). PFI: Construction Performance, HC 567, Session 2002-03, The Stationery Office, London.

PUBLIC ACCOUNTS COMMITTEE (PAC), 2011, Lessons from PFI and other projects, 44th Report of Session 2010-12, HC 1201, September 2011, London: The Stationery Office. 
PUBLIC ACCOUNTS COMMITTEE (PAC), 2018, Private Finance Initiatives, 46th Report of Session 2017-19, HC 894, June 2018, London: The Stationery Office.

PUBLIC WORKS FINANCING (PWF), various years, PWF Newsletter: Survey of PublicPrivate Partnerships, Westfield: Public Works Financing.

ROUMBOUTSOS A. (ed.), 2016, Public Private Partnerships in Transport: Trends and Theory. Cost Programme, London: Routledge.

SHAOUL J., STAFFORD A. and STAPLETON P., 2006, 'Highway robbery? A financial analysis of design, build, finance and operate (DBFO) in UK Roads', Transport Reviews, 257-274.

SHAOUL J., STAFFORD A. and STAPLETON P., 2010, 'Financial black holes: the disclosure and transparency of privately financed roads in the UK', Accounting, Auditing \& Accountability Journal, 229-255.

SHAOUL J., STAFFORD A. and STAPLETON P., 2012, 'The fantasy world of private finance for transport via Public Private Partnerships', International Transport Forum, OECD. Available at: https:/www.internationaltransportforum. org/jtrc/DiscussionPapers/DP201206.pdf

STAFFORD A., ACERETE B. and STAPLETON P., 2010, 'Making concessions: political, commercial and regulatory tensions in accounting for European roads PPPs', Accounting and Business Research, 473-493.

VASSALLO J. M., ORTEGA A. and BAEZA M.Á., 2011, Impact of the economic recession on toll highway concessions in Spain, Journal of Management in Engineering, 398-406.

VERHOEST K. et al., 2016, Chapter 5 In Roumboutsos, A. (ed.) Public Private Partnerships in Transport: Trends and Theory, Cost Programme, Routledge: London.

VILLALBA-ROMERO F. and LIYANAGE C. (2016). 'Implications of the use of different payment models'. International Journal of Managing Projects in Business, 9, 11-32.

WORLD BANK, 2017, Asian Toll Road Development Program: Review of Recent Toll Road Experience in Selected Countries and Preliminary Tool Kit for Toll Road Development.

YSA T., GINÉ M., ESTEVE M. and SIERRA V., 2012, 'Public corporate governance of state-owned enterprises: evidence from the Spanish banking industry', Public Money \& Management, 32, 265-272. 